\section{ASPEK HUKUM PENGELOLAAN PEMBANGUNAN WILAYAH PESISIR DAN PULAU-PULAU KECIL TERLUAR MENURUT UNDANG-UNDANG NOMOR 1 TAHUN 2014 TENTANG PERUBAHAN ATAS UNDANG- UNDANG NOMOR 27 TAHUN 2007 TENTANG PENGELOLAAN WILAYAH PESISIR DAN PULAU- PULAU KECIL ${ }^{1}$ \\ Oleh : Febrianto Gabriello Owen Katiandagho ${ }^{2}$}

\begin{abstract}
ABSTRAK
Tujuan Dilakukannya penelitian ini yakni untuk mengetahui bagaimana strategi pengelolaan pembangunan di wilayah pesisir dan pulaupulau kecil dan bagaimana kebijakan pengelolaan pembangunan di wilayah pesisir dan pulau-pulau kecil di mana dengan menggunakan metode penelitian hukum normatif disimpulkan: 1 . Strategi pengelolaan pembangunan di wilayah pesisir dan pulaupulau kecil dapat dilakukan dengan beberapa proses seperti yang tercantum dalam pasal 5 Undang-Undang Nomor 1 Tahun 2014 Tentang Perubahan Atas Undang-Undang Nomor 27 Tahun 2007 Tentang Pengelolaan Wilayah Pesisir Dan Pulau-Pulau Kecil, yaitu meliputi proses kegiatan perencanaan, pemanfaatan, pengawasan dan pengendalian, dalam mengelola dan memanfaatkan sumber daya pesisir dan pulau-pulau kecil yang
\end{abstract} berkelanjutan. Kegiatan perencanaan meliputi rencana strategis wilayah pesisir dan pulaupulau kecil (RSWP3K), rencana zonani wilayah pesisir dan pulau-pulau kecil (RZWP3K), rencana pengelolaan wilayah pesisir dan pulaupulau kecil (RPWP3K), dan rencana aksi pengelolaan wilayah pesisir dan pulau-pulau kecil (RAPWP3K). kegitan pemanfaatan sendiri lebih kepada konservasi, untuk pendidikan dan pelatihan, budidaya laut dan untuk pariwisata. Sedangkan kegiatan pengawasan dan pengendalian dilakukan pemantauan, pengamanan lapangan dan atau evaluasi terhadap perencanaan dan pelaksanaannya. Selain proses yang disebutkan dalam undangundang tersebut, pengelolaan pembangunan wilayah pesisir dan pulau-pulau kecil secara

\footnotetext{
${ }^{1}$ Artikel Skripsi. Dosen Pembimbing: Dr. Flora pricilla kalalo, SH, MH ; Dr. Denny B. A. Karwur, SH, M.SI

2 Mahasiswa pada Fakultas Hukum Unsrat, NIM. 16071101227
}

terpadu, pengelolaan berbasis lingkungan dan pengelolaan berbasis masyarakat menjadi strategi yang sangat penting untuk dilakukan dalam pengelolaan pembangunan di wilayah pesisir dan pulau-pulau kecil. 2. Kebijakan pengelolaan pembangunan di wilayah pesisir dan pulau-pulau kecil dengan lahirnya UndangUndang Nomor 27 Tahun 2007 Tentang Pengelolaan Wilayah Pesisir Dan Pulau-Pulau Kecil dan dengan upaya pemerintah diubah menjadi Undang-Undang Nomor 1 Tahun 2014 untuk membuat adanya pengakuan dan penghormatan kesatuan-kesatuan masyarakat adat, masyarakat tradisional yang bermukim di wilayah pesisir, dalam hal ini memberikan kepastian hukum bagi masyarakat wilayah pesisir. Selain kebijakan pemerintah membuat undang-undang wilayah pesisir terdapat juga beberapa undang-undang yang mendukung undang-undang ini seperti Undang-Undang Nomor 9 Tahun 2015 Tentang Pemerintahan Daerah, Undang-Undang Nomor 26 Tahun 2007 Tentang Penataan Ruang, selain itu kebijakan lain dilakukan yaitu dengan meningkatkan pengelolaan pulau-pulau kecil di perbatasan untuk menjaga integritas NKRI, dan meningkatkan sinkronisasi peraturan perundang-undangan dan penegakan hukum. Khusus mengenai kebijakan pemerintah dalam pengelolaan sumber daya dilakukan dengan kebijakan sentralistik, berdasarkan pada doktrin, rapat umum, dan pluralisme hukum.

Kata kunci: pesisir; pulau kecil terluar;

\section{PENDAHULUAN}

\section{A. Latar Belakang}

Kegiatan pengelolaan pulau-pulau kecil menghadapi berbagai ancaman baik dari aspek ekologi yaitu terjadinya penurunan kualitas lingkungan, seperti pencemaran, perusakan ekosistem dan penangkapan ikan yang berlebihan (overfishing) maupun dari aspek sosial yaitu rendahnya aksesibilitas dan kurangnya penerimaan masyarakat lokal ${ }^{3}$. Disisi lain juga terlihat eksploitasi sumber daya alam dengan cara merusak seperti penggalian pasir, akibatnya beberapa pulau kecil telah hilang atau tererosi ${ }^{4}$.

\footnotetext{
${ }^{3}$ Karwur Denny,Op.Cit., HIm.2

4 Dep. Kelautan Dan Perikanan, Dirjen Pesisir-Pesisir Pulau-Pulau Kecil, Naskah Akademik Pengelolaan WilayahWilayah Pesisir, Draf 1 Februari 2001, HIm.11
} 
Pengembangan kawasan pulau-pulau kecil merupakan suatu proses yang akan membawa suatu perubahan pada ekosistemnya. Perubahan-perubahan tersebut akan membawa pengaruh pada lingkungan. Semakin tinggi intensitas pengelolaan dan pembangunan yang dilaksanakan berarti semakin tinggi tingkat pemanfaatan sumberdaya, maka semakin tinggi pula perubahan-perubahan lingkungan yang akan terjadi di kawasan pulau- pulau kecil ${ }^{5}$.

\section{B. Rumusan Masalah}

1. Bagaimana strategi pengelolaan pembangunan di wilayah pesisir dan pulau-pulau kecil?

2. Bagaimana kebijakan pengelolaan pembangunan di wilayah pesisir dan pulau-pulau kecil?

\section{Metode Penelitian}

Penulisan ini penelitian hukum Normatif, adapun bentuk penelitian hukum Normatif.

\section{PEMBAHASAN}

\section{A. Strategi Pengelolaan Pembangunan Di} Wilayah Pesisir Dan Pulau-Pulau Kecil

Undang-Undang Nomor 1 Tahun 2014 Tentang Perubahan Atas Undang-Undang Nomor 27 Tahun 2007 Tentang Pengelolaan Wilayah Pesisir Dan Pulau-Pulau Kecil menyatakan beberapa proses dalam melakukan pengelolaan wilayah pesisir dan pulau-pulau kecil yaitu meliputi kegiatan perencanaan, pemanfaatan, pengawasan, dan pengendalian terhadap interaksi manusia dalam memanfaatkan sumber daya pesisir dan pulaupulau kecil serta proses alamiah secara berkelanjutan dalam upaya meningkatkan kesejahteraan masyarakat dan menjaga keutuhan Negara Kesatuan Republik Indonesia ${ }^{6}$.

1. Tahap Perencanaan

Berdasarkan penjelasan umum UndangUndang Nomor 27 Tahun 2007 Tentang Pengelolaan Wilayah Pesisir Dan Pulau-Pulau Kecil dinyatakan bahwa perencanaan dilaksanakan melalui pendekatan pengelolaan wilayah pesisir dan pulau-pulau kecil secara terpadu atau yang dikenal dengan instilah Integrated Coastal Zone Management, yang

\footnotetext{
${ }^{5}$ Karwur Denny, Loc.Cit

6 Undang-Undang Nomor 27 Tahun 2007 Tentang Pengelolaan Wilayah Pesisir Dan Pulau-Pulau Kecil, Pasal 5
}

menginteraksikan berbagai perencanaan yang disusun oleh berbagai sektor terkait dan sesuai dengan tugas dan kewenangan pemerintah pusat dan daerah sehingga terjadi keharmonisan dan penguatan dalam pemanfaatan ${ }^{7}$.

Para ahli di bidang pengelolaan wilayah pantai berpendapat pengelolaan wilayah pantai secara terpadu (Integrated Coastal Zone Management) merupakan kunci bagi pemecahan problem dan konflik di wilayah pantai yang sangat pelik dan kompleks. Keterpaduan dalam manajemen publik dapat didefenisikan sebagai penentuan tujuan secara simultan, melakukan secara bersama-sama pengumpulan informasi, perencanaan dan analisis secara kolektif, penggunaan secara bersama-sama perangkat/instrument pengelolaan ${ }^{8}$.

Tahap perencanaan Undang-Undang kawasan pesisir dan pulau-pulau terluar membagi perencanaan pengelolaan menjadi rencana strategis wilayah pesisir dan pulaupulau kecil (RSWP3K), rencana zonasi wilayah pesisir dan pulau-pulau kecil (RZWP3K), rencana pengelolaan wilayah pesisir dan pulaupulau kecil (RPWP3K), dan rencana aksi pengelolaan wilayah pesisir dan pulau-pulau kecil (RAPWP3K). Rencana Strategis Wilayah Pesisir dan Pulau-Pulau Kecil (RSWP3K) merupakan bagian yang tidak terpisahkan dari rencana pembangunan jangka panjang setiap pemerintah daerah yang wajib mempertimbangkan kepentingan pemerintah dan pemerintah daerah. Jangka waktu RSWP3K pemerintah daerah selama 20 tahun dan dapat ditinjau kembali sekurang-kurangnya lima tahun sekali ${ }^{9}$. Rencana zonasi wilayah pesisir sendiri merupakan arahan pemanfaatan sumber daya di wilayah pesisir dan pulau-pulau kecil pemerintah provinsi dan atau pemerintah kabupaten/kota. Rencana ini diserasikan, diselaraskan dan diseimbangkan dengan

\footnotetext{
${ }^{7}$ Chikmawati, Nurul Fajra, Pengelolaan Wilayah Pesisir Dan Pulau-Pulau Kecil Di Indonesia (Dalam Perspektif Perlindungan Hukum Bagi Hak-Hak Ekonomi Masyarakat Tradisional), Jurnal Hukum Vol. 4 No. 2, HIm. 408

${ }^{8}$ Trinanda, Tommy Cahya, Pengelolaan Wilayah Pesisir Indonesia Dalam Rangka Pembangunan Berbasis Pelestarian Lingkungan, Matra Pembaruan, Jakarta Pusat, 2017, HIm. 80

9 Undang-Undang Nomor 27 Tahun 2007 Tentang Pengelolaan Wilayah Pesisir Dan Pulau-Pulau Kecil, Pasal 8
} 
rencana tata ruang wilayah (RTRW) pemerintah provinsi atau pemerintah kabupaten/kota. Jangka waktu RZWP3K yaitu selama 20 tahun dan dapat ditinjau kembali setiap 5 tahun.

Rencana pengelolaan wilayah pesisir dan pulau-pulau kecil harus memperhatikan mekanisme pelaporan yang teratur dan sistematis untuk menjamin tersedianya data dan informasi yang akurat dan dapat di akses. RPWP3K berlaku selama 5 tahun dan dapat ditinjau kembali sekurang-kurangnya 1 kali. Sedangkan Rencana aksi pengelolaan wilayah pesisir dan pulau-pulau kecil dilakukan dengan mengarahkan rencana pengelolaan dan rencana zonasi sebagai upaya mewujudkan rencana strategis. RAPWP3K ini berlaku 1 sampai dengan 3 tahun.

Tahap awal dari proses perencanaan yaitu dengan cara mengidentifikasi dan mendefinisikan isu dan permasalahan yang ada, yang menyangkut kerusakan sumber daya alam, konflik penggunaan, pencemaran, dimana perlu dilihat penyebab dan sumber permasalahan tersebut. Selanjutnya juga perlu diperhatikan sumber daya alam dan kawasan yang ada yang menyangkut potensi, daya dukung, status, tingkat pemanfaatan, kondisi sosial ekonomi dan budaya setempat ${ }^{10}$, sehingga ketika akan dilakukan pengelolaan terhadap wilayah pesisir dan pulau-pulau kecil tersebut tidak menimbulkan konflik ataupun permasalahan lain yang dapat merugikan masyarakat maupun wilayah tersebut dan memperhatikan kemampuan wilayah untuk generasi mendatang. Untuk itu dalam proses penyusunan rencana strategis perlu diperhatikan asas-asas rencana strategis dalam pengelolaan sumber daya secara optimal dan berkelanjutan yang dapat di terapkan yaitu:

a. Pemanfaatan sumber daya dapat pulih (renewable resources) harus memperhatikan potensi lestarinya (maximum sustainable yield, MSY). Terjadinya pemanfaatan secara berlebihan akan mengancam kelangsungan pemanfaatan sumber daya alam dapat pulih tersebut. Upaya yang harus ditempuh untuk menjaga keberlangsungan sumber daya alam tersebut adalah bahwa setiap kegiatan

\footnotetext{
${ }^{10}$ Mahi, Ali Kabul, Pengembangan Wilayah, Prenadamedia Group, Jakarta, 2018, HIm. 253-254
}

eksploitasi sumber daya alam dapat pulih tidak boleh melebihi potensi lestarinya. Pelaksanaan kuota yang diperbolehkan harus diinformasikan terutama tentang besarnya potensi lestari untuk setiap jenis stok sumber daya alam;

b. Pemanfaatan sumber daya tidak pulih (non-renewable resources) harus dilakukan secara cermat dan bijaksana. Disebabkan karena sumber daya tidak dapat diperbarui, maka pengelolaannya harus seoptimal mungkin. Upaya mencari sumber-sumber energi alternative perlu dilakukan, seperti arus, gelombang, perbedaan salinitas, perbedaan suhu lapisan air, pasang surut. Selain itu, perlu diupayakan sumber-sumber energi alternarif lainnya.

c. Pendayagunaan potensi sumber daya alam sesuai daya dukung lingkungannya. Kegiatan pemanfaatan sumber daya dapat pulih dan tidak dapat pulih, tidak boleh mematikan kegiatan pemanfaatan sumber daya pulih. Dengan kata lain, bahwa pengelolaan lingkungan dalam kaitannya dengan eksploitasi sumber daya tidak pulih (seperti pertambangan, kilang minyak) tidak boleh merusak sumber daya pulih atau bahkan mematikan kegiatan sumber daya pulih ${ }^{11}$.

Rencana strategis pengelolaan sumber daya di kawasan pesisir dan pulau-pulau kecil perlu juga rencana strategis pembangunan untuk menunjang perkembangan wilayah tersebut melalui sarana prasarana untuk memadai kebutuhan masyarakat yang berada di kawasan tersebut. Oleh karena itu dalam setiap perencanaan perlu dilakukan pendekatan pengelolaan pesisir secara terpadu, dengan teknik bahwa pengelolaan pesisir terpadu menjadikan fasilitator optimalisasi keuntungan ekonomi sosial, pemanfaatan sumberdaya alam, serta jasa-jasa lingkungan di wilayah pesisir. Keterpaduan perencanaan dan pengelolaan wilayah pesisir secara terpadu ini mencakup 4 (aspek), yaitu: (1) keterpaduan wilayah/ekologis, (2) keterpaduan sektor, (3) keterpaduan disiplin ilmu dan (4) keterpaduan stakeholder $^{12}$.

\footnotetext{
${ }^{11}$ Ibid, HIm. 241

12 Waluyo Adi, Jurnal Kelautan Permodelan Pengelolaan Wilayah Pesisir Dan Pulau-Pulau Kecil Secara Terpadu
} 
a. Keterpaduan wilayah/ekologis

Secara keruangan dan ekologis wilayah pesisir memiliki keterkaitan antara lahan atas (daratan) dan laut lepas. Hal ini disebabkan karena wilayah pesisir merupakan daerah pertemuan antara daratan dan laut. Dengan keterkaitan kawasan tersebut, maka pengelolaan kawasan pesisir dan laut tidak terlepas dari pengelolaan lingkungan yang dilakukan di kedua kawasan tersebut. Berbagai dampak lingkungan yang mengenai kawasan pesisir dan laut adalah akibat dari dampak yang ditimbulkan oleh kegiatan pembangunan yang dilakukan dilahan atas seperti pertanian, perkebunan, kehutanan, industri, pemukiman dan sebagainya, demikian juga dengan kegiatan yang dilakukan dilaut lepas, seperti kegiatan pengeboran minyak lepas pantai dan perhubungan laut

b. Keterpaduan sektor

Konsekuensi dari besar dan beragamnya sumber daya alam di kawasan pesisir dan laut adalah banyaknya instansi atau sektor-sektor pelaku pembangunan yang bergerak dalam pemanfaatan pesisir dan laut. Kegiatan suatu sektor tidak dibenarkan mengganggu, apalagi sampai mematikan kegiatan sektor lain. Keterpaduan sektor ini, meliputi keterpaduan secara horizontal (antar sektor) dan keterpaduan secara vertikal (dalam satu sektor). Oleh karena itu, penyusunan tata ruang dan panduan pembangunan di kawasan pesisir sangat perlu dilakukan untuk menghindari benturan antara satu kegiatan dangan kegiatan pembangunan lainnya.

c. Keterpaduan disiplin ilmu

Wilayah pesisir dan laut memiliki sifat dan karakteristik yang unik, baik sifat dan karakteristik ekosistem pesisir maupun sosial budaya masyarakat pesisir sehingga dalam mengkaji wilayah pesisir dan laut tidak hanya diperlukan satu disiplin ilmu saja tetapi dibutuhkan berbagai disiplin ilmu yang menunjang

Yang Berbasis Masyarakat,Fakultas Pertanian Universitas Trunojoyo Madura, Madura, 2014, Hal. 76 sesuai dengan karakteristik pesisir dan lautan tersebut.

d. Keterpaduan Stakeholder

Segenap keterpaduan diatas akan berhasil diterapkan apabila ditunjang oleh keterpaduan dari pelaku dan pengelola pembangunan di kawasan pesisir dan laut (stakeholder). Seperti diketahui bahwa pelaku pembangunan dan pengelolaan sumber daya alam wilayah pesisir antara lain terdiri dari pemerintah (pusat dan daerah), masyarakat pesisir, swasta/investor dan juga lembaga swadaya masyarakat yang masing-masing memiliki kepentingan terhadap pemanfaatan sumber daya alam di kawasan pesisir. Penyusunan perencanaan pengelolaan terpadu harus mampu mengakomodir segenap kepentingan pelaku pembangunan sumber daya pesisir dan laut. Oleh karena itu, perencanaan pengelolaan pembangunaN harus menggunakan dua arah yaitu pendekatan top down dan bottom up.

\section{Tahap Pemanfaatan}

Pemanfaatan wilayah pesisir dan pulaupulau kecil diprioritaskan lebih kepada kepentingan antara lain konservasi, untuk pendidikan dan pelatihan seperti pemeliharaan lingkungan yang baik, penelitian dan pengembangan, budidaya laut, untuk pariwisata demi pengembangan kawasan pesisir dan pulau-pulau terluar dengan cara melakukan pengelolaan pembangunan di wilayah yang terlihat strategis, untuk usaha perikanan dan kelautan serta industri perikanan secara lestari, pertanian organik, peternakan dan juga untuk kepentingan pertahanan keamanan negara. Untuk tujuan konservasi, pendidikan dan pelatihan, serta penelitian dan pengembangan, pemanfaatan pulau-pulau kecil dan perairan di sekitarnya wajib memenuhi persyaratan pengelolaan lingkungan, memperhatikan kemampuan dan kelestarian sistem tata air setempat, dan menggunakan teknologi yang ramah lingkungan ${ }^{13}$.

\footnotetext{
13 Undang-Undang Nomor 1 Tahun 2014 Tentang Perubahan Atas Undang-Undang Nomor 27 Tahun 2007 Tentang Pengelolaan Wilayah Pesisir Dan Pulau-Pulau Kecil, Pasal 23
} 
Dalam melakukan Konservasi di wilayah pesisir dan pulau-pulau kecil diselenggarakan untuk menjaga kelestarian Ekosistem Pesisir dan Pulau-Pulau Kecil, melindungi alur migrasi ikan dan biota laut lain, melindungi habitat biota laut dan melindungi situs budaya tradisional. Kawasan konservasi yang mempunyai ciri khas sebagai satu kesatuan ekosistem diselenggarakan untuk melindungi sumber daya ikan, tempat persinggahan dan/atau alur migrasi biota laut lain, wilayah yang di atur oleh adat tertentu, seperti sasi, mane'e, panglima laot, awig-awig dan/atau istilah lain adat tertentu, ekosistem pesisir yang unik dan atau rentan terhadap perubahan. ${ }^{14}$

Pemanfaatan wilayah pesisir dan pulaupulau kecil dikenal pemanfaatan langsung dan tidak langsung. Pemanfaatan secara langsung merupakan kegiatan perseorangan atau badan hukum dalam memanfaatkan sebagian dari wilayah pesisir dan pulau-pulau kecil untuk kegiatan pokoknya. Sedangkan Pemanfaatan secara tidak langsung merupakan kegiatan perseorangan atau badan hukum dalam memanfaatkan sebagian dari wilayah pesisir dan pulau-pulau kecil untuk menunjang kegiatan pokoknya ${ }^{15}$.

Dalam memanfaatkan wilayah pesisir dan pulau-pulau kecil masyarakat memiliki hak serta kewajiban dalam mengelola wilayah tersebut. Undang-Undang Nomor 1 Tahun 2014 Tentang Perubahan Atas Undang-Undang No 27 Tahun 2007 pada pasal 60 ayat 1 menyebutkan hak masyarakat tersebut yaitu:

a. Memperoleh akses terhadap bagian perairan pesisir yan sudah diberi izin lokasi dan izin pengelolaan;

b. Mengusulkan wilayah penangkapan ikan secara tradisional kedalam RZWP3K;

c. Mengusulkan wilayah masyarakat hukum adat ke dalam RZWP3K;

d. Melakukan kegiatan pengelolaan sumber daya pesisir dan pulau-pulau kecil berdasarkn hukum adat yang berlaku yang tidak bertentangan dengan

\footnotetext{
$14 \quad$ Undang-Undang Nomor 1 Tahun 2014 Tentang Perubahan Atas Undang-Undang Nomor 27 Tahun 2007 Tentang Pengelolaan Wilayah Pesisir Dan Pulau-Pulau Kecil, Pasal 28

15 Penjelasan Undang-Undang Nomor 27 Tahun 2007 Tentang Pengelolaan Wilyah Pesisir Dan Pulau-Pulau Kecil, Pasal 35
}

ketentuan peraturan perundangundangan;

e. Meperoleh manfaat atas pelaksanaan pengelolaan wilayah pesisir dan pulaupulau kecil;

f. Memperoleh informasi berkenan dengan pengelolaan wilayah pesisir dan pulaupulau kecil;

g. Mengajukan laporan dan pengadun kepada pihak yang berwenang atas kerugian yamg menimpah dirinya yang berkaitan dengan pelaksanaan pengelolaan wilayah pesisir dan pulaupulau kecil;

h. Menyatakan keberatan terhadap rencana pengelolaan yang sudah di umumkan dalam jangka waktu tertentu;

i. Melaporkan kepada penegak hukum akibat dugaan pencemaran, dan atau perusakan wilayah pesisir dan pulaupulau kecil yang merugikan kehidupannya;

j. Mengajukan gugatan kepada pengadilan terhadap berbagai masalah wilayah pesisir dan pulau-pulau kecil yang merugikam kehidupannya;

k. Memperoleh ganti rugi;

I. Mendapat pendampingan dan bantuan hukum terhadap permasalahan yang dihadapi dalam pengelolaan wilayah pesisir dan pulau-pulau kecil sesuai dengan ketentun peraturan perundangundangan.

m. Sedangkan kewajiban yang harus dipenuhi oleh masyarakat dalam memanfaatkan wilayah pesisir dan pulaupulau kecil diatur dalam pasal 60 ayat 2 yaitu:

a) Memberikan informasi berkenaan dengan pengelolaan wilayah pesisir dan pulau-pulau kecil;

b) Menjaga, melindungi dan memelihara kelestarian wilayah pesisir dan pulaupulau kecil;

c) Menyampaikan laporan terjadinya bahaya, pencemaran, dan/atau kerusakan lingkungan di wilayah pesisir dan pulau-pulau kecil;

d) Memantau pelaksanaan rencana pengelolaan wilayah pesisir dan pulau-pulau kecil; dan 
e) Melaksanakan program pengelolaan wilayah pesisir dan pulau-pulau kecil yang disepakati di tingkat desa.

Pasal 60 ayat (1) ini hanya menyebutkan tentang masyarakat yang berarti masyarakat menurut pasal 1 butir 32 Undang-Undang Nomor 1 Tahun 2014 mengatakan bahwa masyarakat adalah masyarakat yang terdiri atas masyarakat hukum adat, masyarakat lokal, dan masyarakat tradisional yang bermukiman di wilayah pesisir dan pulau-pulau kecil.

Masyarakat lokal (pesisir), menurut pasal 1 butir 34 Undang-Undang Nomor 1 Tahun 2014 masyarakat lokal yaitu masyarakat yang menjalankan tata kehidupan sehari-hari berdasarkan kebiasaan yang sudah diterima sebagai nilai-nilai yang berlaku umum, tetapi tidak sepenuhnya bergantung pada sumber daya pesisir dan pulau-pulau kecil tertentu. Syarat untuk suatu masyarakat ini, yaitu masyarakat yang "menjalani tata kehidupan sehari-hari berdasarkan kebiasaan yang sudah diterima sebagai nilai-nilai yang berlaku umum".

Syarat ini sebenarnya tidak begitu jelas, oleh karena itu istilah ini sebenarnya ditujukan untuk masyarakat yang memiliki kebiasaan atau adat yang telah berlangsung secara turun temurun dan pada hakikatnya lebih dekat kemasyarakat hukum adat, tetapi tidak sepenuhnya merupakan masyarakat hukum adat. Masyarakat lokal adalah kelompok orang atau masyarakat yang mendiami desa/kelurahan pantai dan menjalankan tatanan hukum, sosial dan budaya yang ditetapkan dan ditatati oleh mereka sendiri secara turun-temurun. Hakikat dari istilah masyarakat lokal yaitu masyarakat lokal mencakup masyarakat hukum adat dan masyarakat semi masyarakat hukum adat yaitu mereka yang menjalankan tatanan hukum, sosial dan budaya yang ditetapkan dan ditaati oleh mereka sendiri secara turun temurun. Selanjutnya yang dimaksud masyarakat pesisir perkotaan yaitu masyarakat yang bermukiman di wilayah pesisir perkotaan, pada umumnya bukan merupakan masyarakat hukum adat ataupun masyarakat lokal. Masyarakat pesisir perkotaan lebih tepat disebutkan sebagai masyarakat pesisir karena mereka hanya mendiami wilayah pesisir dan tidak mempunyai kesamaan adat istiadat yang berlaku turun temurun yang dipakai sebagai hukum dalam mengatur hubungan diantara mereka ${ }^{16}$.

3. Tahap pengawasan dan pengendalian

Tahap pengawasan dan pengendalian dilakukan untuk menjamin terselenggaranya pengelolaan wilayah pesisir dan pulau-pulau kecil secara terpadu dan berkelanjutan. Pengawasan dan/atau pengendalian dilakukan oleh pejabat pegawai negeri sipil tertentu yang menangani bidang pengelolaan wilayah pesisir dan pulau-pulau kecil sesuai dengan sifat pekerjaan yang dimilikinya. Dalam melakukan pengawasan dan/atau pengendalian pejabat pegawai negeri sipil berwenang mengadakan patrol/perondaan di wilayah pesisir dan pulaupulau kecil atau wilayah hukumnya serta menerima laporan yang menyangkut perusakan ekosistem pesisir, kawasan konservasi, kawasan pemanfaatan umum dan kawasan strategis nasional tertentu. ${ }^{17}$

\section{B. Kebijakan Pengelolaan Pembangunan Wilayah Pesisir Dan Pulau-Pulau Kecil}

Kebijakan sebagai prinsip-prinsip yang mengatur tindakan yang diarahkan kepada tujuan-tujuan tertentu. Kebijakan senantiasa berorientasi kepada masalah (problem oriented) dan berorientasi kepada tindakan (action oriented). Dengan demikian dapat dinyatakan bahwa kebijakan adalah suatu peraturan atau ketetapan yang mengatur mengenai cara-cara bertindak yang dibuat secara terencana dan konsisten untuk memecahkan masalah yang ada dan untuk mencapai suatu tujuan yang telah ditetapkan. ${ }^{18}$

Sebagai negara hukum, pengaturan mengenai pengelolaan wilayah pesisir memerlukan instrument hukum yang tidak diskriminatif, sebagai sebuah payung hukum dan landasan kebijakannya yang tidak ditemui dalam peraturan perundang-undangan sebelum lahirnya Undang-Undang Nomor 27 Tahun 2007 tentang pengelolaan wilayah pesisir dan pulau-

\footnotetext{
${ }^{16}$ Kalalo Flora, Loc.Cit

17 Undang-Undang Nomor 1 Tahun 2014 Tentang Perubahan Atas Undang-Undang Nomor 27 Tahun 2007 Tentang Pengelolaan Wilayah Pesisir Dan Pulau-Pulau Kecil, Pasal 36

18 Marliana Dian, Dkk, Jurnal Kebijakan Pengelolaan Wilayah Pesisir Berbasis Sustainable Development Di Kabupaten Sampan (Studi Pada Bappeda Kabupaten Sampang), Fakultas IImu Administrasi Universitas Brawijaya, Malang, Hal. 81
} 
pulau kecil yang telah di rubah menjadi Undang-Undang Nomor 1 Tahun 2014. Implikasi lahirnya undang-undang tentang wilayah pesisir dan pulau-pulau kecil di antaranya adalah adanya paradigma pembangunan dari berbasis sumber daya daratan ke sumber daya kelautan.

\begin{tabular}{llr}
\multicolumn{1}{c}{ perubahan } & kebijakan & pengalokasian \\
anggaran & pembangunan & dengan \\
memperhatikan & parameter luas wilayah
\end{tabular}
perairan laut, Perubahan pendekatan pembangunan sesuai dengan karakteristik biogeofisik wilayah pesisir dan pulau-pulau kecil, obligasi bagi pemerintah, dunia usaha, dan masyarakat untuk memitigasi bencana di wilayah pesisir dan pulau-pulau kecil, membuat sepadan pantai dan mengkonversi wilayah pesisir untuk perlindungan, pelestarian biodiversity, perlindungan manusia dari bencana, pelestarian nilai-nilai sosial budaya pesisir. ${ }^{19}$ Namun lahirnya Undang-Undang Nomor 27 Tahun 2007 Tentang Wilayah Pesisir pada proses pemberlakuan undang-undang dianggap kurang menjamin keberlangsungan kesejahteraan masyarakat di wilayah pesisir dalam mengelola dan membangun wilayah tersebut.

Tujuan mengelola pesisir adalah untuk melindungi, memanfaatkan sumber daya pesisir dengan peran serta masyarakat, lembaga, serta pemerintah dalam upaya meningkatkan nilai ekonomi, budaya, dan sosial dalam pemanfaatan sumber daya. Perencanaan dan penataan wilayah pesisir di Indonesia telah ditentukan sedemikian rupa melalui berbagai produk dokumen yang ditetapkan. Kebijakankebijakan pada produk ketentuan pengelolaan pesisir tersebut bertujuan untuk mengontrol dan mengendalikan kegiatan pemanfaatan sumber daya pesisir. ${ }^{20}$ Dalam pengelolaan wilayah pesisir banyak sektor maupun pihak lain yang mempunyai kepentingan pada pembangunan wilayah pesisir membuat kompleksnya pengelolaan wilayah pesisir, sehingga beberapa kebijakan bersifat tumpang tindih bahkan sering bertabrakan, sehingga dapat berdampak pada kerugian yang sangat besar yang dirasakan masyarakat terlebih masyarakat lokal.

\footnotetext{
${ }^{19}$ Trinanda Tommy Cahya, Op.Cit, Hal. 82

${ }^{20}$ Subagiyo Aris, Op. Cit, Hal. 18
}

Dengan terbitnya Undang-Undang Nomor 1 Tahun 2014 membuat adanya pengakuan dan penghormatan kesatuan-kesatuan masyarakat hukum adat serta hak-hak tradisional sesuai dengan prinsip NKRI, dan mengakui serta menghormati masyarakat lokal dan masyarakat tradisional yang bermukin di wilayah pesisir dan pulau-pulau kecil. ${ }^{21}$

Berdasarkan pemikiran ini maka tujuan kebijakan pengelolaan wilayah pesisir dan pulau-pulau kecil sebagaimana disebutkan dalam pasal 4 Undang-Undang Nomor 27 Tahun 2007 Yang Telah Di Rubah Menjadi UndangUndang Nomor 1 Tahun 2014 Tentang Pengelolaan Wilayah Pesisir Dan Pulau-Pulau Kecil, yaitu:

a. Melindungi, mengonservasi, merehabilitasi, memanfaatkan, memperkaya sumber daya pesisir dan pulau-pulau kecil serta sistem ekologisnya secara berkelanjutan;

b. Menciptakan keharmonisan dan sinergi antara pemerintah dan pemerintah daerah dalam pengelolaan sumber daya pesisir dan pulau-pulau kecil;

c. Memperkuat peran serta masyarakat dan lembaga pemerintah serta mendorong inisiatif masyarakat dalam pengelolaan sumber daya pesisir dan pulau-pulau kecil agar tercapai keadilan, keseimbangan, keberlanjutan; dan

d. Meningkatkan nilai sosial, ekonomi, dan budaya masyarakat melalui peran serta masyarakat dalam pemanfaatan sumber daya pesisir dan pulau-pulau kecil.

Selain tujuan kebijakan pengelolaan wilayah pesisir dan pulau-pulau kecil yang telah di atur dalam undang-undang wilayah pesisir, adapun asas kebijakan yang di tentukan oleh pemerintah dimana asas ini merupakan asas berkelanjutan yang diterapkan untuk pengelolaan pembangunan di wilayah pesisir dan pulau-pulau kecil yaitu:

a. Pemanfaatan sumber daya tidak melebihi kemampuan regenerasi sumber daya hayati atau laju inovasi substitusi sumber daya nonhayati pesisir;

b. Pemanfaatan sumber daya pesisir saat ini tidak boleh mengorbankan kualitas dan kuantitas kebutuhan generasi yang akan datang atas sumber daya pesisir; dan

\footnotetext{
${ }^{21}$ Trinanda Tommy Cahya, Op. Cit, Hal. 83
} 
c. Pemanfaatan sumber daya yang belum diketahui dampaknya harus dilakukan secara hati-hati dan didukung oleh penelitian ilmiah yang memadai. ${ }^{22}$

Undang-Undang Nomor 1 Tahun 2014 Tentang Perubahan Atas Undang-Undang Nomor 27 Tahun 2007 Memiliki Kaitan Dengan Undang-Undang Nomor 9 Tahun 2015 Tentang Pemerintahan Daerah. Undang-Undang ini merupakan jalan terang bagi pengelolaan berkelanjutan sebagaimana yang diamanatkan dalam Undang-Undang No 1 Tahun 2014. Dimana kebijakan tentang pemerintah daerah otonomi daerah adalah ingin mendekatkan kebijakan pada wilayah atau masyarakat setempat. Oleh sebab itu, pada prinsipnya dengan adanya otonomi daerah maka pemerintah daerah dan masyarakat dituntut untuk lebih inovatif dan memiliki kreativitas untuk selalu mendorong perekonomian daerah dan tidak merusak potensi sumber daya alam setempat.

Selain undang-undang tentang pemerintahan daerah terdapat beberapa undang-undang yang terkait dengan pengelolaan wilayah pesisir dan pulau-pulau kecil yang mendasari kebijakan dalam mengelola dan membangun wilayah pesisir dan pulau-pulau kecil yaitu:

a. Undang-Undang Nomor 32 Tahun 2009 Tentang Perlindungan Dan Pengelolaan Lingkungan Hidup.

Undang-Undang ini menentukan tujuan perlindungan dan pengelolaan lingkungan hidup yaitu melindungi Wilayah Negara Kesatuan Republik Indonesia dari pencemaran dan/atau kerusakan lingkungan hidup, menjamin keselamatan, kesehatan, dan kehidupan manusia, menjamin kelangsungan kehidupan makhluk hidup dan kelestarian ekosistem, menjaga kelestarian fungsi lingkungan hidup, mencapai keserasian, keselarasan, dan keseimbangan lingkungan hidup, menjamin terpenuhinya keadilan generasi masa kini dan generasi masa depan, menjamin pemenuhan dan perlindungan hak atas lingkungan hidup sebagai bagian dari hak asasi manusia,

\footnotetext{
22 Penjelasan Pasal 3 Huruf A Undang-Undang Nomor 1 Tahun Tahun 2014 Tentang Perubahan Atas UndangUndang Nomor 27 Tahun 2007 Tentang Pengelolaan Wilayah Pesisir Dan Pulau-Pulau Kecil
}

mengendalikan pemanfaatan sumber daya alam bijaksana, mewujudkan pembangunan berkelanjutan, dan mengantisipasi isu lingkungan global.

b. Undang-Undang Nomor 5 Tahun 1960 Tentang Ketentuan Dasar Pokok-Pokok Agraria (UUPA)

Dalam UUPA mengatur tentang hak memerintah oleh negara atas bumi, udara, ruang angkasa, dan kekayaaan alam yang terkandung di dalamnya. Selain itu, juga mengatur hak ulayat, hakatas tanah, dan hak atas udara.

c. Undang-Undang Nomor 5 Tahun 1990 Tentang Konservasi Sumberdaya Hayati Dan Ekosistemnya

Konservasi sumberdaya alam hayati dan ekosistemnya berusaha keras terwujudnya kelestarian sumber daya alam hayati serta keseimbangan ekosistem, sehingga dapat mendukung peningkatan kesejahteraan masyarakat dan kehidupan manusia.

d. Undang-Undang Nomor 4 Tahun 2009 Tentang Pertambangan Mineral Dan Batubara

Undang-Undang ini terkesan lebih menitik dari perhatian pada eksploitasi dari pada kelestarian. Dalam undang-undang terdapat pasal perlindungan lingkungan dari kegiatan pertambangan.

e. Undang-Undang Nomor 26 Tahun 2007 tentang penataan ruang

Pembentukan undang-undang tata ruang berdasarkan pada asas-sasas ruang bagi semua kepentingan, berdaya guna dan berhasil guna, serasi selaras, seimbang dan dikelola dan asas keterbukaan, persamaan, kesejahteraan dan perlindungan hukum. Undang-undang tata ruang, tata ruang mencakup daratan, laut dan udara, membuat undang-undang ini sangat penting dalam pengelolaan wilayah pesisir dan pulau-pulau kecil.

f. Undang-Undang Nomor 18 Tahun 2003 Tentang Kehutanan

Pasal 6 ayat 1 menyebutkan kebijakan yang dibuat pemerintah dalam rangka pencegahan perusakan hutan berupa kordinasi lintas sektor dalam pencegahan dan pemberantasan perusakan hutan, pemenuhan kebutuhan sumber daya aparatur pengamanan hutan, insentif bagi 
para pihak yang berjasa dalam menjaga kelestarian hutan, peta penunjukan kawasan hutan dan atau koordinat geografis sebagai dasar yuridis batas kawasan hutan, dan pemenuhan kebutuhan sarana dan prasarana pencegahan dan pemberantasan perusakan hutan.

g. Undang-Undang Nomor 45 Tahun 2009 Tentang Perubahan Atas Undang-Undang Nomor 31 Tahun 2004 Tentang Perikanan

Dalam undang-undang ini pemerintah melaksanakan pengelolaan sumber daya alam yang lengkap dan terarah dengan melestarikan sumber daya alam bersama untuk lingkungan dan kesejahteraan Indonesia. Kewenangan yang diberikan kepada pemerintah tentang sumber daya ikan masih berjalan semangat sentralistik.

h. Undang-Undang Nomor 6 Tahun 1996 Tentang Perairan

Undang-Undang ini memberikan pengaturan seperti mengatur udara, menentukan dimana udara berada diatas atau dibawah permukaan tanah dan tidak termasuk air yang ada di laut.

i. Undang-Undang Nomor 10 Tahun 2009 Tentang Kepariwisataan

Undang-Undang ini kepariwisataan berfungsi untuk memenuhi kebutuhan jasmani rohani dan intelektual setiap wisatawan dengan rekreasi dan perjalanan serta meningkatkan pendapatan negara untuk mewujudkan kesejahteraan rakyat dan bertujuan untuk meningkatkan pertumbuhan ekonomi, meningkatkan kesejahteraan rakyat, menghapus kemiskinan, mengatasi pengangguran, melestarikan alam lingkungan dan sumber daya, memajukan kebudayaan, mengangkat citra bangsa, menumpuk rasa cinta tana air, memperkuku jati diri dan kesatuan bangsa dan mempererat persahabatan antar bangsa.

j. Undang-Undang Nomor 7 Tahun 2016 Tentang Perlindungan Dan Pemberdayaan Nelayan Pembudidaya Ikan Dan Petambak Garam

Undang-Undang ini sangat berkaitan dengan pengelolaan di kawasan pesisir demi memberikan kepastian bagi para nelayan dalam melakukan usaha yang berkelanjutan.
Berbagai inisiatif pengelolaan pulau-pulau kecil harus dilihat dalam kaitan dengan pemenuhan kebutuhan hidup manusia dan kepentingan pembangunan ekonomi serta geopolitik nasional secara lebih luas yang memenuhi prinsip-prinsip pembangunan berkelanjutan. Prinsip-prinsip pengelolaan pulau-pulau kecil yang harus dilakukan oleh pemerintah, pemerintah provinsi, pemerintah kabutapen/kota dan dunia usaha/swasta yaitu: eksistensi pulau kecil harus di pertahankan sesuai dengan karakteristik dan fungsi yang dimilikinya, efisien dan optimal secara ekonomi, berkeadilan dan dapat diterima secara social budaya, dan secara ekologis tidak melampaui daya dukung lingkungan. ${ }^{23}$

\section{PENUTUP}

\section{A. Kesimpulan}

1. Strategi pengelolaan pembangunan di wilayah pesisir dan pulau-pulau kecil dapat dilakukan dengan beberapa proses seperti yang tercantum dalam pasal 5 Undang-Undang Nomor 1 Tahun 2014 Tentang Perubahan Atas Undang-Undang Nomor 27 Tahun 2007 Tentang Pengelolaan Wilayah Pesisir Dan PulauPulau Kecil, yaitu meliputi proses kegiatan perencanaan, pemanfaatan, pengawasan dan pengendalian, dalam mengelola dan memanfaatkan sumber daya pesisir dan pulau-pulau kecil yang berkelanjutan. Kegiatan perencanaan meliputi rencana strategis wilayah pesisir dan pulau-pulau kecil (RSWP3K), rencana zonani wilayah pesisir dan pulau-pulau kecil (RZWP3K), rencana pengelolaan wilayah pesisir dan pulau-pulau kecil (RPWP3K), dan rencana aksi pengelolaan wilayah pesisir dan pulau-pulau kecil (RAPWP3K). kegitan pemanfaatan sendiri lebih kepada konservasi, untuk pendidikan dan pelatihan, budidaya laut dan untuk pariwisata. Sedangkan kegiatan pengawasan dan pengendalian dilakukan pemantauan, pengamanan lapangan dan atau evaluasi terhadap perencanaan dan pelaksanaannya. Selain

\footnotetext{
${ }^{23}$ Tjiptabudy Jantje, Aspek Hukum Pengelolaan Wilayah Pesisir Dan Pulau-Pulau Kecil Terhadapa Eksistensi Masyarakat Adat, Fakultas Hukum Universitas Pattimura, Ambon, 2013
} 
proses yang disebutkan dalam undangundang tersebut, pengelolaan pembangunan wilayah pesisir dan pulaupulau kecil secara terpadu, pengelolaan berbasis lingkungan dan pengelolaan berbasis masyarakat menjadi strategi yang sangat penting untuk dilakukan dalam pengelolaan pembangunan di wilayah pesisir dan pulau-pulau kecil.

2. Kebijakan pengelolaan pembangunan di wilayah pesisir dan pulau-pulau kecil dengan lahirnya Undang-Undang Nomor 27 Tahun 2007 Tentang Pengelolaan Wilayah Pesisir Dan Pulau-Pulau Kecil dan dengan upaya pemerintah diubah menjadi Undang-Undang Nomor 1 Tahun 2014 untuk membuat adanya pengakuan dan penghormatan kesatuan-kesatuan masyarakat adat, masyarakat tradisional yang bermukim di wilayah pesisir, dalam hal ini memberikan kepastian hukum bagi masyarakat wilayah pesisir. Selain kebijakan pemerintah membuat undangundang wilayah pesisir terdapat juga beberapa undang-undang yang mendukung undang-undang ini seperti Undang-Undang Nomor 9 Tahun 2015 Tentang Pemerintahan Daerah, UndangUndang Nomor 26 Tahun 2007 Tentang Penataan Ruang, selain itu kebijakan lain dilakukan yaitu dengan meningkatkan pengelolaan pulau-pulau kecil di perbatasan untuk menjaga integritas NKRI, dan meningkatkan sinkronisasi peraturan perundang-undangan dan penegakan hukum. Khusus mengenai kebijakan pemerintah dalam pengelolaan sumber daya dilakukan dengan kebijakan sentralistik, berdasarkan pada doktrin, rapat umum, dan pluralisme hukum.

\section{B. Saran}

1. Dalam pengelolaan dan pembangunan wilayah pesisir dan pulau-pulau kecil telah mengalami kemajuan namun pemerintah harus mengikut sertakan masyarakat pesisir dalam menyusun dan/atau menjalankan strategi dalam mengelola dan membangun kawasan perbatasan karena pada hakikatnya masyarakat pesisir yang lebih mengetahui wilayah mereka. Selain itu pemerintah juga harus lebih meningkatkan pelayanan bagi masyarakat seperti penyuluhan dalam meningkatkan pengetahuan masyarakat dalam mengelola dan membangun wilayah mereka dengan lebih baik lagi dan untuk membantu masyarakat dalam meningkatkan pertumbuhan ekonomi. Pemerintah juga harus lebih memperhatikan aspek pelestarian ekosistem agar wilayah pesisir dan pulaupulau kecil lebih terjaga, dengan kata lain pemerintah harus merombak strategi yang ada menjadi lebih baru dengan memperhatikan perkembangan wilayah dan tidak hanya berpatokan pada daftar strategi yang sudah ada yang bisa saja tidak sejalan atau tidak sesuai lagi dengan wilayah tersebut.

2. Kebijakan pemerintah yang dilakukan saat ini dapat dikatakan berjalan dengan baik dengan adanya perubahan undangundang yang mengatur wilayah pesisir dan pulau-pulau kecil. Akan tetapi pemerintah harus lebih memperhatikan penyediaan produk hukum yang lebih mumpuni demi terjaminnya hak dari masyarakat. Penyediaan produk hukum itu dapat berupa peraturan daerah dengan menggagas sebuah model yang berbasis masyarakat. Pemerintah juga dalam menjalankan kebijakan belum pernah memberikan otonomi yang nyata dalam pemanfaatan sumberdaya pesisir di wilayah pesisir dan pulau-pulau kecil sehingga membuat wilayah ini susah berkembang dan menjadi terkebelakang dalam hal perekonomian, karena kegiatan ekonomi yang berlangsung dilakukan berdasarkan pendekatan sektor yang hanya menguntungkan instansi sektoral dan usaha tertentu. Oleh sebab itu pemerintah harus lebih meingkatkan kebijakannya dalam mengelola dan membangun wilayah pesisir dan pulau-pulau kecil untuk perkembangan yang lebih baik dan untuk pelayanan bagi masyarakat wilayah pesisir dan pulau-pulau kecil. 


\section{DAFTAR PUSTAKA}

Anak Agung, Jurnal Model Pengelolan Wilayah Pesisir Berbasisi Masyarakat, Fakultas Hukum Unversitas Udayana, Bali, 2018

Beatley. T, D. J. Bower And A.K. Schwab, An Introdution To Coastal Zones Management, Islands Press, Washington D.C, 1994, Dalam Rokhmin Dahuri, Dkk

Bengen, D.G. Menuju Pengelolaan Wilayah Pesisir Terpadu Berbasis DAS. SEMINAR HUT LIPI, Jakarta, 25-26 September 2002

Budiardjo Miriam, Dasar-Dasar IImu Politik, Gramedia, Jakarta, 1985

Chikmawati , Nurul Fajra, Pengelolaan Wilayah Pesisir Dan Pulau-Pulau Kecil Di Indonesia (Dalam Perspektif Perlindungan Hukum Bagi Hak-Hak Ekonomi Masyarakat Tradisional), Jurnal Hukum Vol. 4 No. 2

Dep. Kelautan Dan Perikanan, Dirjen PesisirPesisir Pulau-Pulau Kecil, Naskah Akademik Pengelolaan Wilayah-Wilayah Pesisir, Draf 1 Februari 2001

Draft I, Naskah Akademik Pengelolaan Wilayah Pesisir, Departemen Kelautan Dan Perikanan, Jakarta, 2001

Ilham Marasabessy, Dkk, Jurnal Strategi Pengelolaan Berkelanjutan Pesisir Dan Laut Pulau Nusa Manu Dan Pulau Nusa Lun Di Kabupaten Maluku Tengah, FPIK Institut Pertanian Bogor, Bogor, 2018

II Yulianto, Perlindungan Dan Pengelolaan Lingkungan Dikawasan Pesisir Dan PulauPulau Kecil, Fakultas Hukum Universitas Jenderal Soedirman, Purwokerto, 2011

Irwandi Idris, Dkk, Membangunkan Raksasa Ekonomi, PT Sarana Komunikasi Utama, Bogor, 2007

Irwan Hesty,Dkk, Penelitian Hukum Tentang Aspek Hukum Pengelolaan Pulau-Pulau Kecil Di Indonesia, Jakarta 2012

Jurnal Hukum Lingkungan, Peranan Hukum Dalam Mewujudkan Konsep Pembangunan Yang Berkelanjutan Oleh Moestadji, ICEL, Jakarta, 1994

Kalalo, Flora Pricilla, Hukum Lingkungan Dan Kebijakan Pertanahan Di Wilayah Pesisir, PT. Rajagrafindo Persada, Jakarta 2016

Karwur Denny, Rancangbangun Hukum Dalam Pengelolaan Pulau-Pulau Kecil Terluar Kasus Pulau Marore Dan Pulau Miangas Provinsi Sulawesi Utara, Bogor 2010
Kismartini Dan Bungin Burhan, Wilayah Peisir Indonesia (Narasi Kebijakan Publik Masalah Pesisir Dan Pulau-Pulau Kecil Di Indonesia) Kencana, Jakarta, 2019

Kusnadi, Strategi Hidup Masyarakat Nelayan, PT. Lkis Printing Cemerlang, Yogyakarta, 2013

Mahi, Ali Kabul, Pengembangan Wilayah, Prenadamedia Group, Jakarta, 2018

Marfai, Muh Aris, Kajian Daya Dukung Dan Ekosistem Pulau Kecil Studi Kasus Pulau Pari, Gadjah Mada University Press, Yogyakarta, 2018

Marliana Dian, Dkk, Jurnal Kebijakan Pengelolaan Wilayah Pesisir Berbasis Sustainable Development Di Kabupaten Sampan (Studi Pada Bappeda Kabupaten Sampang), Fakultas IImu Administrasi Universitas Brawijaya, Malang

Muhammad Sahri, Kebijakan Pembangunan Perikanan Dan Kelautan (Pendekatan Sistem), Universitas Brawijaya Press (UB Press), Malang, 2011

Parlindungan, A.P, Hak Pengelolaan Menurut Sistem UUPA (Undang-Undang Pokok Agraria), Mandar Maju, Bandung, 1989

Pedoman Umum Pengelolaan Pulau-Pulau Kecil Yang Berkelanjutan Dan Berbasis Masyarakat, DEP. Kelautan\&Perikanan (Dirjen Pesisir Dan Pulau-Pulau Kecil), Jakarta 2001

Rohmin Dahuri, Dkk, Pengelolaan Sumber Daya Wilayah Pesisir Dan Lautan Secara Terpadu, PT Pradnya Paramita, Jakarta, 2001

Rukin, Pembangunan Perekonomian Masyarakat Desa Mandiri, Zifatama Jawara, Pondok Jati, 2019

Satria Arif, Pengantar Sosiologi Masyarakat Pesisir, Yayasan Pustaka Obor Indonesia, Jakarta, 2015

Sitorus Oloan Dan H.M Zaki Sierrad, Hukum Agrarian Di Indonesia, Konsep Dasar Dan Implementasi, Mitra Kebijakan Tanah Indonesia, Yogyakarta, 2006

Tamboto Henry, Model Pengentasan Kemiskinan Masyarakat Pesisir, Cv,Seribu Bintang, Malang,2019

Tjiptabudy Jantje, Aspek Hukum Pengelolaan Wilayah Pesisir Dan Pulau-Pulau Kecil Terhadapa Eksistensi Masyarakat Adat, Fakultas Hukum Universitas Pattimura, Ambon, 2013 
Lex Et Societatis Vol. VIII/No. 1/Jan-Mar/2020

Trinanda, Tommy Cahya, Pengelolaan Wilayah Pesisir Indonesia Dalam Rangka Pembangunan Berbasis Pelestarian Lingkungan, Matra Pembaruan, Jakarta Pusat, 2017

Waluyo Adi, Jurnal Kelautan Permodelan Pengelolaan Wilayah Pesisir Dan PulauPulau Kecil Secara Terpadu Yang Berbasis Masyarakat,Fakultas Pertanian Universitas Trunojoyo Madura, Madura, 2014

Yonvitner, Dkk, Pengertian, Potensi, Dan Karakteristik Wilayah Pesisir 